\title{
Identification and Dosage by HRGC of Minor Alcohols and Esters in Brazilian Sugar-Cane Spirit
}

\author{
Maurício Boscolo, Cícero W. B. Bezerra, Daniel R. Cardoso, Benedito S. Lima Neto, Douglas W. Franco* \\ Instituto de Química de São Carlos - Universidade de São Paulo - \\ Av. Dr. Carlos Botelho, 1465 - CP 780 - 13560-970 - São Carlos - SP, Brazil.
}

\begin{abstract}
A presença de 51 compostos voláteis, entre álcoois e ésteres, em aguardentes de cana (cachaça) foi investigada por cromatografia gasosa de alta resolução. Os seguintes compostos foram identificados e quantificados: metanol, 1,4-butanodiol, álcool 2-feniletílico, álcool amílico, álcool cetílico, álcool cinâmico, n-decanol, geraniol, álcool isoamílico, isobutanol, mentol, n-butanol, ndodecanol, n-propanol, n-tetradecanol, propionato de amila, acetato de etila, benzoato de etila, heptanoato de etila, valerato de isoamila, propionato de metila, butirato de propila. O teor médio de álcoois superiores ( $262 \mathrm{mg} / 100 \mathrm{~mL}$ de álcool anidro a.a.) e o teor médio de ésteres ( $24 \mathrm{mg} / 100$ $\mathrm{mL}$ a.a.) em cachaças são menores que os encontrados em outros destilados. $\mathrm{O}$ teor médio de metanol em cachaças, $(6 \mathrm{mg} / 100 \mathrm{~mL}$ a.a.) é o mesmo que o encontrado em rum e menor em relação ao encontrado em destilados de uva. Com relação aos compostos analisados, não foram observadas diferenças significativas no perfil químico qualitativo das cachaças analisadas.
\end{abstract}

The presence of 51 volatile compounds, among alcohols and esters in Brazilian sugar-cane spirit (cachaça), were investigated by high-resolution gas chromatography (HRGC). The following alcohols and esters were identified and quantified: methanol, 1,4-butanodiol, 2-phenylethyl alcohol, amyl alcohol, cetyl alcohol, cynamic alcohol, n-decanol, geraniol, isoamyl alcohol, isobutanol, menthol, n-butanol, n-dodecanol, n-propanol, n-tetradecanol, amyl propionate, ethyl acetate, ethyl benzoate, ethyl heptanoate, isoamyl valerate, methyl propionate, propyl butyrate. The average higher alcohols content ( $262 \mathrm{mg} / 100 \mathrm{~mL}$ in anhydrous alcohol a.a.) and total esters content $(24 \mathrm{mg}$ / $100 \mathrm{~mL}$ a.a.) in cachaças, are smaller than in other spirits. The average methanol content in cachaças $(6 \mathrm{mg} / 100 \mathrm{~mL}$ a.a.) is the same as in rum, but smaller than in wine spirit. No qualitative differences of chemical profile among cachaças have been observed.

Keywords: sugar-cane spirit, cachaça, higher alcohols, esters.

\section{Introduction}

Brazilian sugar-cane spirit, which has been popularized in the world as "cachaça" (ca-sha-sa), is the most consumed spirit in Brazil ${ }^{1}$. The production of cachaça is estimated in two billion liters per year ${ }^{2}$.

Cachaça is produced from the distillation of the sugarcane juice which was fermented by Saccharomyces cerevisiae and its ethanol content, according to the Brazilian regulation $^{3}$, must be in the range of 38 to $54 \% \mathrm{v} / \mathrm{v}$. The aging process is not yet a common practice among cachaça producers, therefore, in general, cachaça is consumed as distilled.

Like other spirits, cachaça is mainly characterized organolepticaly by the presence of other minor components such as higher alcohols, esters, carboxylic acids and carbonilic compounds, which are important for the taste and flavor of spirits 4,5 . These compounds are formed from carbohydrates and amino acids during amino acid biosynthesis and catabolism, respec- tively 6 . The comparison of the aldehydes and carboxylic acids fractions in cachaças have been previously reported 7,8 .

The knowledge of the cachaça chemical components is a matter of concern, not only to distillers or inspection bureau, but to for analytical chemists due to the chemical complexity of the matrix and the low level of analyte occurrence.

The current official analytical procedures are based on volumetric methodology, therefore precluding any type of speciation. As the sensorial properties and toxicology of compounds change along the homologues series, it is relevant to know more details about each chemical category present in the spirits 8 .

Aiming to contribute to the cachaça chemical quality control, this study reports the occurrence and dosage of minor alcohols and esters in cachaças, establishing an average of their chemical composition. For this purpose, highresolution gas chromatography with a flame ionization detector (HRGC-FID) was used. 


\section{Experimental}

\section{Materials}

The analyses were carried out in a Hewlett-Packard 5890A GC equipped with a split-splitless inlet injector and a flame ionization detector (FID). Two fused silica capillary columns were used: HP-FFAP cross-linked poly(ethylene glycol)-TPA phase; (50m x 0.2mm I.D. x 0.33 $\mu \mathrm{m}$ film thickness) and HP-20M Carbowax: poly( ethylene glycol); (50m x $0.32 \mathrm{~mm}$ I.D. x $0.33 \mu \mathrm{m}$ film thickness). Chromatographic data were collected in HP chemstation software.

Chemicals of analytical grade from Merck, Aldrich Chemicals and Carlo Erba were used as standards. The presence of the following compounds was investigated: methyl alcohol, n-propyl alcohol, 2-propyl alcohol, n-butyl alcohol, 2-butyl alcohol, isobutyl alcohol, t-butyl alcohol, 1,3-butyl alcohol, 1,4-butyl alcohol, n-pentyl alcohol, isoamyl alcohol (mixture of 2-methyl-butyl and 3-methyl-butyl), 2-pentyl alcohol, 3pentyl alcohol, neo-pentyl alcohol, n-hexyl alcohol, 2-hexyl alcohol, n-octyl alcohol, 2-octyl alcohol, n-decyl alcohol, ndodecyl alcohol, n-tetradecyl alcohol, menthol, geraniol, allyl alcohol, cynamic alcohol, cetyl alcohol, ethylene glycol, propylene glycol, 2-phenylethyl alcohol, 2-amino-2-methyl1-propyl alcohol, 2-amino-1-butyl alcohol, methyl formate, ethyl formate, methyl acetate, ethyl acetate, n-propyl acetate, isopropyl acetate, n-butyl acetate, isobutyl acetate, sec-butyl acetate, n-pentyl acetate, isopentyl acetate, n-hexyl acetate, ethyl propanoate, isobutyl propanoate, ethyl heptanoate, ethyl butyrate, methyl benzoate, ethyl benzoate, methyl miristate and methyl stearate. These compounds were chosen to be investigated based on the their occurrence in other spirits 9,10 .

Twenty five regular commercial cachaças from different regions of Brazil* were analyzed: Caninha da $\operatorname{Roça(SP),~}$ Caranguejo(CE), Chave de Ouro(CE), Pirassununga 51(SP), Jamel(SP), Oncinha(SP), Pitu(SP), Velho Barreiro(SP), Ypioca Ouro(CE), Ypioca Prata(CE), Germana(MG), Ganyvit(SP), São Francisco(RJ), Marquesi(SP), Massayo(AL), Azuladinha(AL), Trinca 3(CE), Vila Velha(SP), Box 32(SC), Lua Cheia(MG), Cavalinho(SP), Salinas(MG), Baronesa(MG), Bodoco(MG) and Sapupara(CE).

\section{Experimental conditions}

Inlet and detector temperatures: $250^{\circ} \mathrm{C}$; Injected volume: $1.0 \mu \mathrm{L}$; split ratio: variable, but generally 1:20; carrier gas: hydrogen $\left(1.2 \mathrm{mLmin}^{-1}\right)$; oven temperature program

*Abreviations for the Brazilian states: (AL) Alagoas; (CE) Ceará; (MG) Minas Gerais; (RJ) Rio de Janeiro; (SC) Santa Catarina; (SP) São Paulo.
(HP-FFAP): $55^{\circ} \mathrm{C}(5 \mathrm{~min}) ; 2^{\circ} \mathrm{C} \mathrm{min}^{-1} \longrightarrow 100^{\circ} \mathrm{C}(3 \mathrm{~min}), 5^{\circ} \mathrm{C}$ $\min ^{-1} \longrightarrow 190^{\circ} \mathrm{C}(30 \mathrm{~min}) ; 5^{\circ} \mathrm{C} \mathrm{min}^{-1} \longrightarrow 220^{\circ} \mathrm{C}(15 \mathrm{~min})$; oven temperature program (HP-20M) $45^{\circ} \mathrm{C} ; 1^{\circ} \mathrm{C} \mathrm{min}^{-1} \longrightarrow$ $100^{\circ} \mathrm{C}(3 \mathrm{~min}), 5^{\circ} \mathrm{C} \mathrm{min}^{-1} \longrightarrow 190{ }^{\circ} \mathrm{C}(30 \mathrm{~min}) ; 5^{\circ} \mathrm{C} \mathrm{min}^{-1} \longrightarrow$ $220^{\circ} \mathrm{C}(15 \mathrm{~min})$. The identification was made through standard addition and using both columns, although quantitative determinations of the identified peaks were accomplished using the HP-FFAP column.

\section{Sample preparation}

In a typical procedure, $300 \mathrm{~mL}$ of the cachaça or standard solutions were added into a $500 \mathrm{~mL}$ separation funnel and two extractions were performed by liquid-liquid extraction (LLE) with two fractions of $40 \mathrm{~mL}$ of pentane:methylene chlorine $(2: 1 \mathrm{v} / \mathrm{v})^{11}$. The samples were spiked with internal standards (n-hexanol) which is absent in cachaças. The extracted volume was reduced by evaporation to $5 \mathrm{~mL}$ The standard curves always showed correlation coefficients close to unit. Some compounds, like ethyl acetate, methanol, n-propanol, isobutanol and isoamyl alcohol (2-methyl1-butanol and 3-methyl-1-butanol), were quantified by injection of the samples without any treatment.

\section{Results and Discussion}

Figures 1 and 2 show typical chromatographic profiles of a cachaça analyzed by direct injection of the sample and from the injection of its extract, respectively.

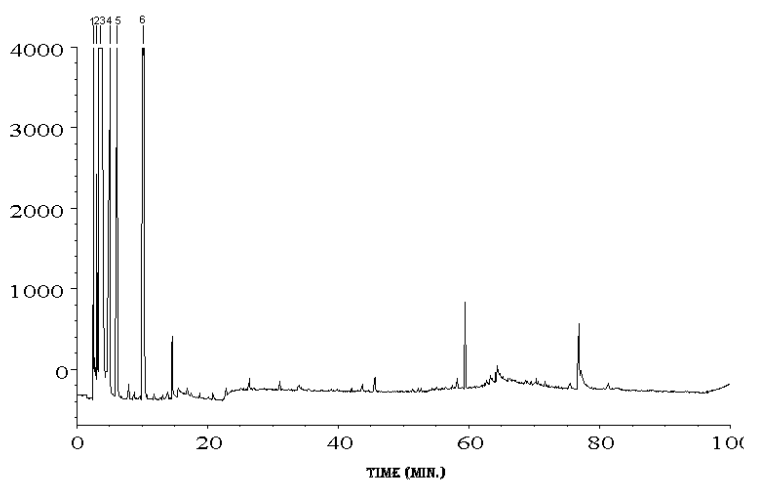

Figure 1. HRGC-FID chromatogram of a cachaça sample obtained by direct injection. HP-FFAP chromatographic column $(50 \mathrm{~m} x$ $0.2 \mu \mathrm{m}$ I.D. x $0.33 \mathrm{~mm}$ fiolm thickness) was used, see experimental conditions. (1) ethyl acetate; (2) methanol; (3) ethanol; (4) promanol; (5) isobutanol; (6) iso-amyl alcohol. Numberless peaks are unknow compounds.

Among 51 analytical standards investigated at the detection level of $10.0 \mu \mathrm{g} \mathrm{L}^{-1}, 23$ compounds were positively identified and quantified. The alcohol and ester content in the samples are shown in Tables 1 and 2, respectively. 


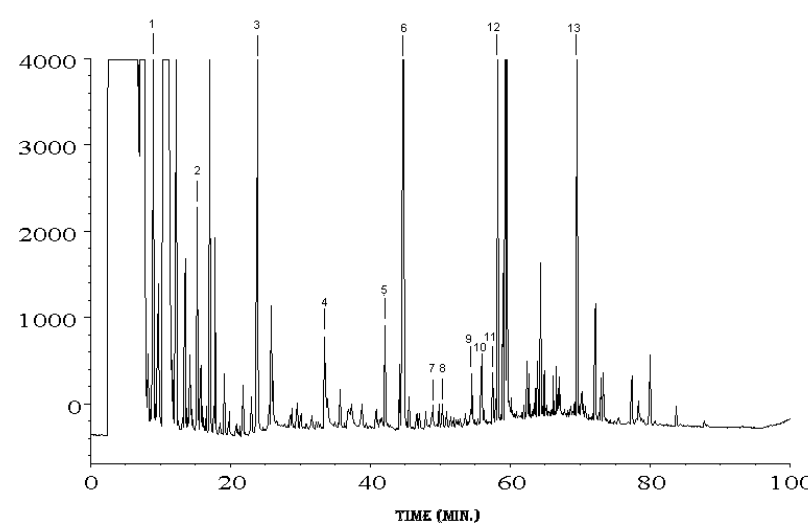

Figure 2. HRCC-FID chromatogram of an extract from the same cachaça in Figure 1. HP-FFAP chromatographic column $(50 \mathrm{~m} \times$ $0.2 \mu \mathrm{m}$ I.D. x $0.33 \mathrm{~mm}$ fiolm thickness) was used, see experimental conditions. (1) propyl butirate; (2) amyl alcohol; (3) ethyl heptanoate; (4) amyl propionate; (5) mentol; (6) ethyl benzoate; (7) 1,4 butanodiol; (8) 2-phenylethyl alcohol; (9) decanol; (10) dodecanol; (11) tetradecanol; (12) cynamic alcohol; (13) cetyl alcohol. Numberless peaks are unknow compounds.

The Brazilian limit values for total esters and total higher

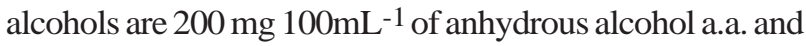
$300 \mathrm{mg} 100 \mathrm{~mL}^{-1}$ a.a., respectively. ${ }^{3}$ These limits do not specify which chemical is present in cachaças.

As it can be observed in Tables 1 and 2, the mean values presented for higher alcohols and ester content are smaller than the allowed limit values. In general, the higher alcohols content are near to the limit and the ester mean content is about one tenth of the limit.

Many of the compounds found incachaças are reported to occur in spirits. However, in general, no quantitative data are available for these minor compounds. In Table 3, cachaça and other spirits are compared regarding some specific common compounds present in their composition.

The average content of n-propanol and n-butanol in cachaças is at the same level of other spirits, while isobutanol is less abundant in cachaças. Rum exhibits smaller isoamyl alcohol content than cachaças, while in whisky and wine spirit samples this alcohol is twice as abundant as in cachaças. Amyl alcohol content in cachaça is surprisingly smaller than in whisky and rum.

Ethyl acetate is the main ester in alcoholic beverages and its higher concentration in cachaças is about half of the one found in rum and whisky. The fact that the total ester content in cachaça is smaller in relation to other beverages probably reflects that cachaças are, in general, nonaged beverages.

No high methanol content has been found in any cachaça. The mean methanol content in regular commercial cachaças is smaller than the reported values for wine spirits, but it is at the same level of the rum. There is no mention for the methanol quantification in whisky.

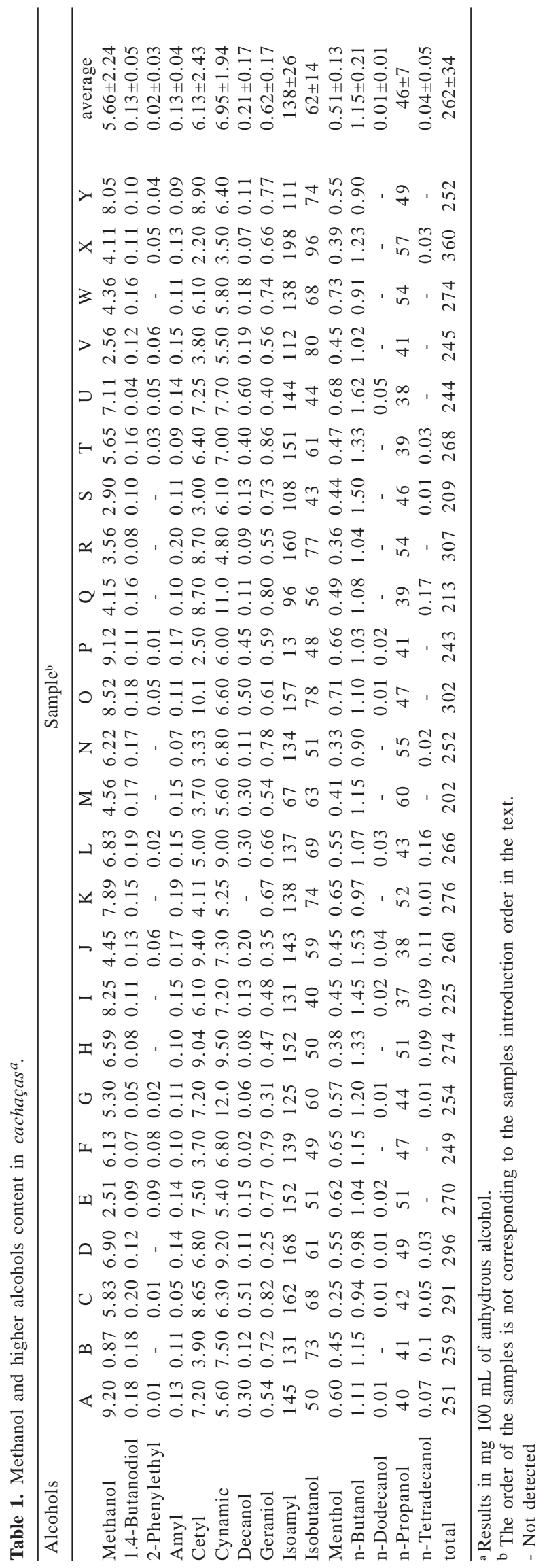


Table 3. Comparison of methanol, higher alcohols and ethyl acetate among different spirits ${ }^{\mathrm{a}}$.

\begin{tabular}{lcccc}
\hline Compound & Cachaça & Rum $^{\mathrm{b}}$ & Whiskyc $^{\mathrm{c}}$ & Wine $^{\mathrm{d}}$ \\
\hline Methanol & 5.7 & 6.6 & & 22 \\
Amyl alcohol & 0.13 & 8.7 & 97 & \\
Isoamylalcohol & 136 & 104 & 250 & 230 \\
Isobutanol & 63 & 162 & 90 & 136 \\
n-butanol & 1.11 & 1.00 & 0.40 & \\
n-propanol & 48 & 38 & 31 & 44 \\
Total alcohols & $263 \mathrm{e}$ & 314 & 468 & 410 \\
Ethyl acetate & 23.5 & 69.7 & 74.1 &
\end{tabular}

a Results in mg $100 \mathrm{~cm}^{-3}$ a.a.; ${ }^{\mathrm{b}}$ (Sing et al 1995); c (Reazin 1981); (Lurton et al 1995);

e All alcohols studied; blank (not mentioned).

The methanol level in blood for acute intoxication is about $100 \mathrm{mg} 100 \mathrm{~L}^{-1} .13$ According to the results in Table 1, an adult weighing $70 \mathrm{~kg}$ should ingest about $180 \mathrm{~L}$ of regular commercial cachaça to undergo methanol intoxication.

Recently, some Brazilian newspapers have reported cases of methanol intoxication due to cachaça ingestion. This poisoning is directly related to beverages prepared and sold on "moonshine style", without any type of chemical control. The Brazilian Ministry of Agriculture ${ }^{3}$ has established a limit of $0.25 \mathrm{~mL}$ (200 mg) of methanol in $100 \mathrm{~mL}$ a.a.

The origin of the high methanol content in these products is quite controversial, but surely the regular fermentation and distillation process do not account for that. As far as we know, there are no cases of methanol poisoning reported as a consequence of regular commercial cachaças ingestion.

The results reported here and in a previous paper 7 have shown that the average content of aldehydes and higher alcohols in cachaças is smaller than in whisky. These two classes of compounds are considered to contribute to the "hangover" syndrome.

By taking into account the above comments and the qualitative chemical profile of cachaça, whisky, rum and wine spirits, a moderate Brazilian sugar-cane spirit intake is expected to cause no health problems.

\section{Conclusions}

The minor alcohols and esters content in cachaças was investigated. This study has clearly shown that the level of methanol content in cachaça is the same as in rum, but smaller than in wine spirit. Higher alcohols content in cachaças is smaller than in rum, whisky and wine spirit. The same occurs with the total esters content.

The average values for higher alcohols in cachaças are slightly smaller than the Brazilian regulation limit and the esters average content is about one tenth of this limit. 


\section{Acknowledgements}

The authors would like to thank CAPES, FAPESP and Ind. Müller de bebidas for the financial support and to Angela C. P. Gianpedro and the referees for the english revision.

\section{References}

1. Impact International, October/November, 1996, p.76.

2. Lima-Neto, B. S.; Franco, D. W. Engarrafador Moderno 1994, 5, 33.

3. BRASIL (Diário Oficial da União), Decreto 73267, de 06/12/1972.

4. Lurton, L.; Snakkers, G.; Roulland, C.; Galy, B. J. Sci. Food Agric. 1995, 67, 485.

5. Suomalainen,H.; Lehtonen, M. J. Inst. Brew. 1979, 85, 149.

6. Korhola, M.; Harju, K.; Lehtonen, M. In The Science and Technology of Whiskies, Piggott, J. R.; Sharp, R.; Duncan, R. E. B.; (Eds.). Longman, Harlow, Essex, England, p 89.

7. Nascimento, R. F.; Marques, J. C.; Lima-Neto, B. S.; Franco, D. W. J. Chromatogr. 1997, 782,13.

8. Nascimento R. F.; Cardoso D. R.; Lima-Neto, B. S.; Franco, D. W. Chromatographia. 1998, 48, 758.

9. Sing, A. S. C.; Smadja, J.; Gaydou, E. M. Lebensm.Wiss.u.-Technol. 1995, 28, 123.

10. Benn, M. S.; Peppard, T. L. J. Agric. Food Chem. 1996, 44, 557.

11. Bezerra, C. W. B. Dissertação de Mestrado. IQSCUSP, São Carlos, 1994, p 53.

12. Reazin, G. H. Am. J. Enol. Vitic. 1981, 32, 283.

13. Casarett \& Doull's Toxicology. The Basic Science of Poisons. Fifth edition. Klaassen, C. D.; Ed. McGraw Hill; New York, 1996, p 756.

Received: August 19, 1999. 